\title{
PENYALAHGUNAAN PERIZINAN PERKEBUNAN SAWIT DALAM PERSPEKTIF TINDAK PIDANA KORUPSI
}

\author{
Mispansyah Mispansyah, Nurunnisa Nurunnisa \\ Fakultas Hukum Universitas Lambung Mangkurat, Banjarmasin \\ mispansyah@ulm.ac.id
}

\begin{abstract}
Abstrak
Tujuan dari penelitian ini adalah: pertama, untuk menganalisis penyalahgunaan perizinan di sektor perkebunan sawit dikategorikan sebagai tindak pidana; kedua untuk menganalsis kebijakan formulasi terhadap tindak pidana penyalahgunaan perizinan perkebunan sawit dimasa mendatang. Urgensi penelitian, karena korupsi di sektor perkebunan sawit di Indonesia terjadi penyalahgunaan penerbitan izin dan berpotensi merugikan keuangan negara. Pasal 14 UU Pemberantasan Tindak Pidana Korupsi (UU PTPK) membuka peluang ketentuan di luar UU PTPK dapat ditarik dalam ketentuan tindak pidana korupsi, namun dengan syarat bahwa UU tersebut menyatakan bahwa pelanggaran terhadap ketentuan pidana dalam UU tersebut merupakan tindak pidana korupsi. Metode penelitian yang digunakan adalah metode penelitian hukum normatif. Hasil penelitian yaitu: Pertama, berdasarkan kasus Martias Alias Pung Kian Hwa dan Kasus H.Suwarna Abdul Fatah, kasus tersebut adalah penyalahgunaan perizinan berkaitan dengan kehutanan dan perkebunan, namun izin tetap dikeluarkan. Penggunaan ketentuan UUPTPK terhadap kasus tindak pidana penyalahgunaan perizinan disektor perkebunan oleh Penegak Hukum tidak tepat, karena Undang-Undang Kehutanan dan UU Perkebunan tidak menyebutkan bahwa tindak pidana penyalahgunaan izin dalam UU Perkebunan merupakan tindak pidana korupsi. Kebaharuan dalam penelitian ini terdapat di bagian kedua, yaitu berupa kebijakan formulasi kedepan terhadap penyalahgunaan perizinan sektor perkebunan kelapa sawit yaitu harus melakukan revisi terhadap undang-undang kehutanan dan undang-undang perkebunan dengan menambah ketentuan pasal yang menyatakan bahwa tindak pidana penyalahgunaan perizinan perkebunan merupakan tindak pidana korupsi.
\end{abstract}

Kata kunci: Izin; Korupsi; Perkebunan; Sawit

\section{ABUSE OF OIL PLANTATION LICENSING IN CORRUPTION PERSPECTIVE}

\begin{abstract}
The purpose of study these are:first, to analyze the misuse of permits in sectors of plantation of oil is categorized as acts of crime; second, to analyze the formulation of policies against criminal acts of misuse of oil palm plantation permits in the future. The urgency of the research, because of corruption in the sector plantation of palm in Indonesia accurred misuse issuance of permits and potentially detrimental to the financial state. Article 14 of Law Combating Acts of Criminal Corruption (UU PTPK) opens oppurtunitiens provision in the outer UU PTPK can be drawn in the provisions of acts of criminal corruption, but with the proviso that the Act that states that violation of the provisions of the criminal in the Act that the acts of riminal corruption. Methods the study that is used is a method of research legal normative. Results of the study are: First, according to the case Martias alias Pung Kian Hwa and Case H.Suwarna Abdul Fatah, a case that is a misuse of licenses relating to forestry and plantations, but the license remains excluded. Use of the terms UU PTPK against cases of acts of Criminal abuse of the licensing sector plantation by the Enforcement Law is not appropriate, because the Law of Forestry and Plantation Act does not mention that the offense of criminal misuse of permits in Plantation Act is an offense of criminal corruption. Novelty in research is contained in part two, namely in the form of policy formulation in the future against the misuse of licensing sector plantations of coconut oil that should do the revision of the law of forestry law plantation to add to the provision of article which states that the acts of criminal abuse.
\end{abstract}

Keywords: Permission; Corruption; Plantation; Palm 


\section{PENDAHULUAN}

\section{A. Latar Belakang}

Kerusakan yang ditimbulkan dari korupsi pada sektor di bidang sumber daya alam tidak hanya berkaitan dengan negara, masyarakat, individu, tetapi berdampak kepada seluruh umat manusia dan lingkungan hidup. ${ }^{1}$ Salah satu bentuk korupsi sumber daya alam adalah korupsi dalam hal izin perkebunan, dalam hal ini berhubungan dengan kekuasaan (penguasa). Tindak pidana dalam pembukaan lahan perkebunan sawit yang tidak prosedural tidak saja menimbulkan kerusakan ekologi namun juga menyebabkan kerugian keuangan negara yang jumlahnya sangat fantanstis. ${ }^{2}$ Berdasarkan penelitian dari Emerson Yuntho data Kementerian Kehutanan yaitu pada Agustus 2011 lalu menyebutkan potensi kerugian negara akibat izin pelepasan kawasan hutan di 7 provinsi di Indonesia diprediksi merugikan negara hampir Rp 273 triliun. Kerugian negara tersebut timbul akibat pembukaan 727 Unit Perkebunan dan 1722 unit pertambangan yang dinilai bermasalah. ${ }^{3}$

Adanya praktik korupsi di bidang perizinan perkebunan sawit salah satunya yang dilakukan dengan cara melakukan suap kepada pejabat daerah. Praktek suap umumnya dilakukan dalam dua bentuk. Pertama, suap untuk setiap izin perkebunan sawit yang dikeluarkan. Disebutkan untuk mengantongi izin perkebunan memang sama sekali tidak dipungut biaya. Tetapi, kenyataanya untuk mengantongi sebagai syarat beroperasi sebuah perkebunan kelapa sawit, seorang pengusaha mesti merogoh kocek hingga miliaran rupiah kepada pejabat daerah. Kedua, praktik suap pemberian ijin perkebunan dilakukan berdasarkan luas perkebunan sawit yang dimintakan izin.

Beberapa peneliti terdahulu antara lain oleh Yuntho (2014) ini lebih menampilkan potret gambaran mengenai korupsi di sektor perkebunan sawit di Indonesia, serta modus operansi yang dilakukan, kemudian potensi undangundang yang dapat digunakan penegak hukum (Penyidik Pegawai Negeri Sipil, Penyidik Polri dan Penyidik Kejaksaan) dapat menerapkan beberapa undangundanga terkait yaitu Undang-Undang Kehutanan, Undang-Undang Perkebunan, Undang-Undang Tindak Pidana Korupsi, Undang-Undang Tindak Pidana Pencucian Uang, ${ }^{4}$ jadi analisisnya secara umum. Berbeda dengan artikel ini yang lebih spesifik pada analasis dalam Pasal 14 UUPTK.

\footnotetext{
${ }^{1}$ Ddisetiansah_anticorrupt, "Tindakan Korupsi Terhadap Sumber Daya Alam Yang Terjadi Di Bumi Papua,” Blogger, 2012, http://riotpositive.blogspot.com/.

2 Emerson Yuntho, "Potret Korupsi Di Sektor Perkebunan Sawit," Jurnal Toddoppuli, 2014, 15, https://jurnaltoddoppuli.wordpress.com/2014/10/20/potret-korupsi-di-sektor-perkebunan-sawit/.

3 Yuntho.

4 Yuntho.
} 
Begitu juga dengan penelitian oleh Yuwanto (2016) dengan judul: "Kinerja Penanganan Tindak Pidana Korupsi Sumber Daya Alam dan Kepercayaan Terhadap Komisi Pemberantasan Korupsi," mengenai kinerja KPK dan kepercayaan masyarakat dalam hal ini subjek penelitian 300 mahasiswa yang concern dengan permasalahan penanganan tindak pidana korupsi sumber daya alam di Indonesia, sangat berbeda dengan artikel dalam penulisan ini. Penelitian oleh Muhdar (2020) yang berjudul "Rekonstruksi Basis Perhitungan Kerugian Negara Dalam Peristiwa Tindak Pidana Korupsi Pada Sektor Sumber Daya Alam."6 Artikel ini membahas mengenai penghitungan kerugian negara dalam kaitan dengan tindak pidana korupsi di sector sumber daya alam, jadi artikel ini jelas berbeda dengan artikel dalam penulisan ini.

Sedangkan penelitian Rasad (2018) dengan judul "Korupsi dan Hak Asasi Manusia dalam Sektor Kehutanan,"7 ini lebih fokus menelaah relasi antara korupsi dan Hak Asasi Manusia (HAM) dalam sektor kehutanan, jadi artikel ini jauh berbeda dengan artikel dalam penulisan ini. Begitu juga artikel dengan judul "Pencegahan Terhadap Tindak Pidana Korupsi Pemerintahan Desa: Kajian Politik Kebijakan Dan Hukum Pengelolaan Sumber Daya Alam Desa," 8 penelitian oleh Makhmudah (2016) ini lebih fokus kepada kajian politik hukum pengelolaan sumber daya alam desa.

Artikel ini memiliki perbedaan dengan beberapa penelitian dipublikasikan dalam artikel di atas memang mengenai tindak pidana di sektor sumber daya alam, namun ada kelemahannya karena tidak membahas dan menelaah mengenai ketentuan Pasal 14 UUPTPK dan pasal yang memungkinkan dapat dikenakan terhadap pelaku dalam UUPTPK, dengan syarat ketentuan di luar UUPTPK harus menyatakan bahwa tindak pidana tersebut merupakan tindak pidana korupsi, dan perlu diketahui bahwa peraturan-perundang-undangan yang mengatur sektor sumber daya alam tidak menyebut hal demikian. Jadi, artikel ini memiliki kelebihan yaitu adanya formulasi kebijakan hukum pidana yang ditawarkan dalam artikel ini terhadap kekosongan hukum yang ada saat ini.

\footnotetext{
5 Listyo Yuwanto, "Kinerja Penanganan Tindak Pidana Korupsi Sumber Daya Alam Dan Kepercayaan Terhadap Komisi Pemberantasan Korupsi," Integritas Jurnal Antikorupsi 2, no. 1 (2016): 1, https://doi.org/https://doi.org/10.32697/integritas.v2i1.137.

${ }^{6}$ Muhamad Muhdar, "Rekonstruksi Basis Perhitungan Kerugian Negara Dalam Peristiwa Tindak Pidana Korupsi Pada Sektor Sumber Daya Alam," Jurnal de Jure 12, no. 1 (2020): 1-2, https://jurnal.law.uniba-bpn.ac.id/index.php/jurnaldejure/article/view/374.

7 Fauziah Rasad, "Korupsi Dan Hak Asasi Manusia Dalam Sektor Kehutanan," Jurnal HAM 9, no. 2 (2018): 1, https://doi.org/http://dx.doi.org/10.30641/ham.2018.9.121-138.

8 Hayat and Mar'atul Makhmudah, "Pencegahan Terhadap Tindak Pidana Korupsi Pemerintahan Desa: Kajian Politik Kebijakan Dan Hukum Pengelolaan Sumber Daya Alam Desa,” Yustisia Jurnal Hukum 5, no. 2 (2016): 1-2, https://doi.org/https://doi.org/10.20961/yustisia.v5i2.875.
} 
Pasal 14 UUPTPK yang menyatakan bahwa: "Setiap orang yang melanggar ketentuan undang-undang yang secara tegas menyatakan bahwa pelanggaran terhadap ketentuan undang-undang tersebut sebagai tindak pidana korupsi berlaku ketentuan yang diatur dalam undang-undang ini." Penelitian ini bertujuan mengoptimalkan pemberlakuan UUPTPK yang banyak memiliki kekhususan, ketentuan Pasal 14 UUPTPK ini memperluas cakupan dari ketentuan UUPTPK terhadap ketentuan peraturan perundangundangan lainnya.

\section{B. Permasalahan}

Apakah penyalahgunaan perizinan di sektor perkebunan sawit dikategorikan sebagai tindak pidana korupsi sudah tepat dan bagimanakah kebijakan formulasi terhadap tindak pidana penyalahgunaan perizinan perkebunan sawit dimasa mendatang?

\section{Metode Penelitian}

Penelitian ini menggunakan tipe penelitian hukum normatif (normative legal research) disebut juga penelitian kepustakaan, ${ }^{9}$ ada juga yang menyebut penelitian hukum doktrinal, ${ }^{10}$ yaitu penelitian dengan menggunakan bahan hukum sebagai obyek penelitian yaitu bahan hukum primer, bahan hukum sekunder dan bahan hukum tersier. Bahan hukum tersebut yang digunakan untuk mengganalisis pertama penyalahgunaan perizinan di sektor perkebunan sawit dikategorikan sebagai tindak pidana korupsi sudah tepat. Kedua kebijakan formulasi terhadap tindak pidana penyalahgunaan perizinan perkebunan sawit dimasa mendatang.

Penelitian ini bersifat perskriptif yaitu menganalisis lebih mendalam mengenai, mengganalisis pertama penyalahgunaan perizinan di sektor perkebunan sawit dikategorikan sebagai tindak pidana korupsi sudah tepat. Kedua kebijakan formulasi terhadap tindak pidana penyalahgunaan perizinan perkebunan sawit dimasa mendatang.

Penelitian ini meneliti adanya kekaburan hukum mengenai tindak pidana korupsi disektor perizinan perkebunan sawit. Adapun penelitian ini menggunakan 3 tipe pendekatan yaitu:

a Perundang-undangan (Statute Approach) pendekatan perundangundangan yaitu Undang-Undang Nomor 39 Tahun 2014 tentang Perkebunan dan Undang-Undang Nomor 31 Tahun 1999 sebagaimana diubah dengan Undang-Undang Nomor 20 Tahun 2001 tentang

\footnotetext{
1986).

9 Soerjono Soekanto, Pengantar Penelitian Hukum, Cet Ke-3 (Jakarta: Universitas Indonesia, 10 Peter Mahmud Marzuki, Penelitian Hukum, Cet Ke-3 (Jakarta: Kencana Prenada Media Group, 2007).
} 
Perubahan atas Undang-Undang Nomor 31 Tahun 1999 tentang pemberantasan Tindak Pidana Korupsi (UUPTPK).

b Konseptual (Conceptual Approach), ${ }^{11}$ yaitu suatu tipe pendekatan untuk menghasilkan analisis mengenai penyalahgunaan perizinan di sektor perkebunan sawit dikategorikan sebagai tindak pidana korupsi sudah tepat. Kedua kebijakan formulasi terhadap tindak pidana penyalahgunaan perizinan perkebunan sawit dimasa mendatang.

c Pendekatan kasus, (Case Approach) ${ }^{12}$ tipe ini termasuk dalam penelitian hukum normatif, ${ }^{13}$ dengan mempelajari norma-norma atau kaidah hukum yang diterapkan dalam praktik hukum. Oleh karena itu pendekatan kasus berupa penerapan.

Prosedur pengumpulan bahan hukum primer dengan cara studi kepustakaan dengan menginventarisasi peraturan perundang-undangan yang berkaitan dengan penelitian yang dibahas. Kemudian buku-buku teks, hasil penelitian baik penelitian, jurnal ilmiah, majalah, surat kabar, buletin, juga menginventarisir yurisprudensi-yurisprudensi, berkenaan tema yang diangkat. Bahan-bahan tersebut kemudian dikualifikasikan dan disistematisasi disusun dengan sistem kartu (card system) sehingga memudahkan proses pengolahan dan analisis.

Keseluruhan bahan hukum yang diperoleh, baik bahan hukum primer maupun sekunder diolah dan dianalisis secara kualitatif, yaitu dari bahan yang diperoleh disusun secara sistematis untuk mencapai kejelasan dari masalah yang dibahas. Analisis terhadap bahan hukum secara kualitatif adalah suatu cara penelitian yang menghasilkan analisis, yaitu dengan menjelaskan dan menginterpretasikan secara logis dan sistematis bahan yang diperoleh dari hasil penelitian.

Analisis bahan hukum menggunakan teori yang digunakan dalam penelitian ini sebagai pisau analisis, menganalisis: pertama penyalahgunaan perizinan di sektor perkebunan sawit dikategorikan sebagai tindak pidana korupsi sudah tepat. Kedua kebijakan formulasi terhadap tindak pidana penyalahgunaan perizinan perkebunan sawit dimasa mendatang. Kemudian dari analisis tersebut ditarik suatu kesimpulan dan saran.

1 Marzuki.

12 Marzuki.

13 Soerdjono Soekanto and Sri Mamudji, Penelitian Hukum Normatif Suatu Tinjauan Singkat, Cet Ke-14 (Jakarta: PT.RajaGrafindo Persada, 2012). 


\section{HASIL DAN PEMBAHASAN}

\section{A. Penyalahgunaan Perizinan Di Sektor Perkebunan Sawit Dikategorikan Sebagai Tindak Pidana Korupsi.}

Berdasarkan penelitian sentra utama kelapa sawit Indonesia (dalam wujud minya sawit) pada tahun 2011 terdapat di 5 (lima) Provinsi, yaitu Riau, Sumatra Utara, Kalimantan Tengah, Sumatera Selatan dan Jambi. Riau berada di peringkat pertama dengan kontribusi sebesar 28,96 persen terhadap total produksi minyak sawit nasional, sedangkan provinsi lain memberikan kontribusi kurang dari 15 persen. ${ }^{14}$ Temuannya seluas 2,8 juta hektar kebun sawit berada di kawasan hutan, $35 \%$ dikuasai masyarakat, $65 \%$ pengusaha. Izin pelepasan dan izin pinjam pakai kawasan hutan pun pada beberapa kasus tak melalui skema perizinan reguler atau ilegal. ${ }^{15}$

Praktek korupsi dengan berbagai modus terjadi mulai dari proses perizinan pembukaan lahan pekebunan sawit hingga penghindaran dari pajak. Nilai kerugian negara yang ditimbulkan juga luar biasa mencapai miliaran sampai triliunan rupiah. ${ }^{16}$

Pemerintah berupaya mengatur tata kelola perkebunan kelapa sawit yaitu dalam Peraturan Menteri Pertanian Nomor 98/Permentan/OT.140/9/2013 tentang Pedoman Perizinan Usaha Perkebunan. Ada tiga poin penting yang diatur di dalam peraturan ini. Pertama, terkait tata cara dan prosedur usaha perkebunan termasuk perkebunan kelapa sawit. Kedua, adanya pembatasan penguasaan lahan perkebunan oleh perusahaan atau group perusahaan dalam satu manajemen yang sama seluar 100.000 hektar. Ketiga, kewajiban perusahaan perkebunan kelapa sawit yang mengajukan IUP seluas 250 hektar atau lebih untuk membangun kebun masyarakat (plasma) paling kurang 20\% dari total lahan yang akan dikembangkan oleh perusahaan kelapa sawit. ${ }^{17}$

\footnotetext{
14 "Pusat Kajian Informasi Pertanian, No 01/01/I" (Jakarta, 2013).

15 Tommy Apriando, "Kajian UGM: 2,8 Juta Hektar Kebun Sawit Di Kawasan Hutan, 65\% Milik Pengusaha, Solusinya?," Mongabay Situs Berita Lingkungan, 2018, https://www.mongabay.co.id/2018/11/04/kajian-ugm-28-juta-hektar-kebun-sawit-di-kawasan-hutan-65milik-pengusaha-solusinya/.

16 Yuntho, "Potret Korupsi Di Sektor Perkebunan Sawit."

17 Komisi Pemberantasan Korupsi, Kajian Sistem Pengelolaan Komoditas Kelapa Sawit (Jakarta: Direktorat Penelitian dan Pengembangan Kedeputian Bidang Pencegahan Komisi Pemberantasan Korupsi Republik Indonesia, 2016).
} 
p-ISSN : 2541-2345, e-ISSN : 2580-8842

Tabel 2: Luas Areal Sawit untuk Wilayah Kalimantan Tahun 2015-2019

\begin{tabular}{|c|c|c|c|c|c|c|c|}
\hline \multicolumn{6}{|c|}{$\begin{array}{l}\text { Luas Areal Kelapa Sawit Menurut Provinsi di Indonesia, 2015-2019 } \\
\text { Palm Oil Area by Province in Indonesia, 2015-2019 }\end{array}$} & $\begin{array}{l}\text { Pertumbu } \\
\text { Growth } \\
\text { over } 2016\end{array}$ & $\begin{array}{l}2017 \\
\%)\end{array}$ \\
\hline No & Daerah & 2015 & 2016 & 2017 & 2018 & 2019 & \\
\hline 1. & $\begin{array}{l}\text { Kalimantan } \\
\text { Barat }\end{array}$ & $\begin{array}{l}1,144,18 \\
5\end{array}$ & $\begin{array}{l}1,264,43 \\
5\end{array}$ & $\begin{array}{l}1,504,78 \\
7\end{array}$ & $\begin{array}{l}1,532,59 \\
8\end{array}$ & $\begin{array}{l}1,570,67 \\
5\end{array}$ & 19.01 \\
\hline 2. & $\begin{array}{l}\text { Kalimantan } \\
\text { Tengah }\end{array}$ & $\begin{array}{l}1,142,00 \\
4\end{array}$ & $\begin{array}{l}1,288,12 \\
8\end{array}$ & $\begin{array}{l}1,480,98 \\
8\end{array}$ & $\begin{array}{l}1,512,33 \\
9\end{array}$ & $\begin{array}{l}1,532,73 \\
4\end{array}$ & 14.97 \\
\hline 3. & $\begin{array}{l}\text { Kalimantan } \\
\text { Selatan }\end{array}$ & 421,068 & 553,144 & 587,799 & 592,425 & 605,449 & 6.27 \\
\hline 4. & $\begin{array}{l}\text { Kalimantan } \\
\text { Timur }\end{array}$ & 849,609 & $\begin{array}{l}1,021,31 \\
4\end{array}$ & $\begin{array}{l}1,059,99 \\
0\end{array}$ & $\begin{array}{l}1,083,28 \\
6\end{array}$ & $\begin{array}{l}1,107,43 \\
7\end{array}$ & 3.79 \\
\hline 5. & $\begin{array}{l}\text { Kalimantan } \\
\text { Utara }\end{array}$ & 157,426 & 50,347 & 249,952 & 251,870 & 258,384 & 396.46 \\
\hline
\end{tabular}

Sumber: Direktorat Jenderal Perkebunan

Data dari Tabel 2 menunjukkan luas areal perkebunan kelapa sawit untuk wilayah Kalimantan dalam kurun waktu 2015-2019. Berdasarkan Permentan Nomor 104 Tahun 2015 Pasal 1, perusahaan yang memegang izin lokasi dan IUP, tetapi areanya berada di dalam kawasan hutan produksi konversi, menurut aturan dapat mengajukan pelepasan kawasan hutan. Kemudian Pasal 5 Permentan Nomor 104 Tahun 2015 Pasal 5 yaitu : Pelepasan kawasan hutan adalah perubahan peruntukan kawasan hutan produksi yang dapat di konversi menjadi bukan kawasan hutan. Peraturan Menteri Lingkungan Hidup dan Kehutaan Nomor P51/Menlhk/Setjen/KUM.1/6/2016 dalam Pasal 4 ayat 1 menyebutkan bahwa pemerintah melalui Menteri Lingkungan Hidup dan Kehutanan (KLHK) diberikan kewenangan untuk mengeluarkan Surat Keputusan (SK) Pelepasan Kawasan Hutan.

Pelepasan kawasan hutan pada kawasan hutan produktif konversi dilakukan pada hutan produksi yang tidak produktif. Dan tidak dapat diproses pada provinsi yang luas kawasan hutan sama dengan atau kurang dari 30\%, kecuali dengan cara tukar menukar kawasan hutan. Adapun mengenai tata cara pelepasan kawasan hutan diatur dalam Peraturan Menteri Lingkungan Hidup dan Kehutanan Nomor P51/Menlhk/Setjen/KUM.1/6/2016 tentang Tata Cara Pelepasan Kawasan Hutan Produksi yang dapat dikonversi. 
Dalam rangka untuk memuluskan izin tersebut, para pengusaha melakukan suap terhadap pejabat berwenang. Praktek suap umumnya dilakukan dalam dua bentuk. Pertama, suap untuk setiap izin perkebunan sawit yang dikeluarkan. Dugaan suap dalam proses peizinan perbunan sawit pernah disampaikan oleh Wakil Ketua DPRD Provinsi Kalimantan Barat, berinisal AU. Disebutkan untuk mengantongi izin perkebunan memang sama sekali tidak dipungut biaya. Tetapi, kenyataanya untuk mengantongi sebagai syarat beroperasi sebuah perkebunan kelapa sawit, seorang pengusaha mesti merogoh kocek hingga miliaran rupiah. Sebagai contoh di Kabupaten Seruyan, Kalimantan Tengah. Investigasi yang dilakukan Lumbung Informasi Rakyat (LIRA) menyebutkan di Kabupaten Seruyan untuk mendapatkan 1 (satu) izin lokasi, pengusaha perkebunan dipungut biaya Rp. 4 milyar.

Kedua, suap berdasarkan luas perkebunan sawit yang dimintakan izin. Sawit Watch menyebutkan bahwa biaya penerbitan izin lokasi untuk setiap hektar kebun sawit sebesar Rp 500.000 - Rp 1 juta/ha, atau rata-rata Rp 750 juta untuk izin lokasi seluas 1.000 ha. Contoh lainnya korupsi perolehan izin di lahan perkebunan adalah tertangkapnya Bupati Buol Amran Batalipu oleh KPK dengan sangkaan menerima suap dalam penerbitan HGU PT Hardaya Inti Plantations. Selain Bupati Buol, KPK juga menetapkan pengusaha Hartati Murdaya sebagai tersangka dalam kasus tersebut. ${ }^{18}$ Kasus suap terhadap anggota DPRD Kalteng dinilai sebagai poin pertama dari mekanisme izin usaha kelapa sawit di Indonesia yang belum berjalan dengan baik. ${ }^{19}$

Berikut ini dalam artikel ini disajikan kasus korupsi suap dalam proses perizinan yaitu putusan terhadap terdakwa Syahrial Oesman. Kasus II dengan terdakwa H. Annas Maamun, ${ }^{20}$ kasus III tindak pidana korupsi dengan terdakwa 1 Rita Widya Sari dan terdakwa II Khairuddin. ${ }^{21}$

Berdasarkan contoh kasus tindak pidana korupsi di atas adalah korupsi suap dalam proses perizinan di perkebunan kelapa sawit, dan bukan karena penyalahgunaan perizinan di sektor perkebunan kelapa sawit. Untuk kasus suap dalam proses perizinan, memang sudah tetap menggunakan UUPTPK, yaitu Pasal 5, Pasal 6, Pasal 11, Pasal 12, Pasal 13.

\footnotetext{
18 Korupsi.

19 Rahmad Fauzan, "Korupsi DPRD Kalteng Bukti Mekanisme Izin Kelapa Sawit Belum Berjalan Baik," Bisnis.com, 2018, https://kabar24.bisnis.com/read/20181027/16/853848/korupsi-dprdkalteng-bukti-mekanisme-izin-kelapa-sawit-belum-berjalan-baik.

20 Mahkamah Agung Republik Indonesia, "Putusan Pengadilan Negeri Bandung Nomor 35/Pid.Sus-TPK/2015/PN.Bdng”. Mahkamah Agung Republik Indonesia, 2015,Jakarta.

21 Mahkamah Agung Republik Indonesia, "Putusan Pengadilan Negeri Jakarta Nomor.10.Pid.Sus-TPK/2018/PN-Jkt Pst”, Mahkamah Agung Republik Indonesia, 2015,Jakarta.
} 
Tabel: 3 Kasus Korupsi Terdakwa Martias alias Pung Kian Hwa

\begin{tabular}{|c|c|c|c|}
\hline Terdakwa & Ketentuan Pidana & Bentuk Pidana Penjara & $\begin{array}{l}\text { Bentuk } \\
\text { Denda }\end{array}$ \\
\hline $\begin{array}{l}\text { Martias Alias Pung } \\
\text { Kian Hwa }\end{array}$ & $\begin{array}{lrrr}\text { Pasal } & \text { 3 UU } & \text { Nomor } \\
31 & & \\
\text { Tahun } & 1999 & \text { jo } & \text { UU } \\
\text { Nomor } & 20 & \text { Tahun } \\
2001 & & & \end{array}$ & $\begin{array}{l}\text { Paling singkat } 1 \\
\text { tahun dan paling lama } 20 \\
\text { tahun }\end{array}$ & $\begin{array}{l}\text { Paling sedikit } \\
\text { Rp 50juta juta dan } \\
\text { paling banyak Rp } 1 \\
\text { milyar }\end{array}$ \\
\hline Tuntutan Jaksa & $\begin{array}{l}\text { Pidana Penjara } 9 \text { thn tahun } \\
\text { kurungan ; Uang Penggant } \\
\text { penjara }\end{array}$ & $\begin{array}{l}\text { dan denda Rp 300juta } S \\
\text { i : Rp346.823.970.564,24 }\end{array}$ & $\begin{array}{l}\text { sidair } 6 \text { (enam) bulan } \\
\text { bsidair } 3 \text { (tiga) tahun }\end{array}$ \\
\hline Putusan Kasus & $\begin{array}{l}\text { Pengadilan tingkat } \\
\text { pertama }\end{array}$ & $\begin{array}{l}\text { Pengadilan tingkat } \\
\text { banding }\end{array}$ & $\begin{array}{l}\text { Pengadilan tingkat } \\
\text { kasasi }\end{array}$ \\
\hline $\begin{array}{l}\text { Martias Alias } \\
\text { Pung Kian Hwa }\end{array}$ & $\begin{array}{l}\text { No } \\
\text { 21/PID.B/TPK/2006/PN } \\
\text { JKT.PST, Tgl. 03 Mei } \\
2007 \\
\text { Pidana Penjara : 1 (satu) } \\
\text { tahun } 6 \text { (enam) bulan ; } \\
\text { Denda } \\
\text { Rp200.000.000,- } \\
\text { Subsidair 6 (enam) } \\
\text { bulan kurungan; } \\
\text { Uang Pengganti : } \\
\text { Rp4.600.341.467,-- } \\
\text { Subsidair 1 (satu) tahun } \\
\text { penjara }\end{array}$ & $\begin{array}{l}\text { No: } \\
\text { 05/PID/TPK/2007/PT.D } \\
\text { KI, Tgl. 06 Agustus } 2007 \\
\text { Menerima permintaan } \\
\text { banding yang diajukan } \\
\text { oleh Terdakwa Martias } \\
\text { alias Pung Kian Hwa dan } \\
\text { Penuntut Umum pada } \\
\text { Komisi Pemberantasan } \\
\text { Korupsi }\end{array}$ & $\begin{array}{l}\text { No : } \\
\text { K/Pid.Sus/2007, Tgl. } \\
\text { 11 Desember 2007 } \\
\text { Pidana Penjara : } 1 \\
\text { (satu) tahun } 6 \text { (enam) } \\
\text { bulan; } \\
\text { Denda } \\
\text { Rp500.000.000,- } \\
\text { Subsidair } \\
\text { (sepuluh) } \\
\text { kurungan ; bulan } \\
\text { Uang Pengganti : } \\
\text { Rp346.823.970.564,- } \\
\text { Subsidair 1 (satu) } \\
\text { tahun 6 (enam) bulan } \\
\text { penjara. }\end{array}$ \\
\hline
\end{tabular}


Kasus II adalah H.Suwarna Abdul Fatah ${ }^{22}$

Tabel:4 Kasus Korupsi Terdakwa H. Suwarna Abdul Fatah

\begin{tabular}{|c|c|c|c|c|}
\hline \multicolumn{2}{|l|}{ Terdakwa } & Ketentuan pidana & Bentuk Pidana & Bentuk \\
\hline \multicolumn{2}{|c|}{ H.Suwarna Abdul } & Pasal 2 ayat (1) jo Pasal 18 & Paling $\quad$ singkat & Paling \\
\hline \multicolumn{2}{|l|}{ Fatah } & \begin{tabular}{lrr} 
UU No. & 31 & Th \\
1999 & & tentang \\
Pemberantasan & Tindak \\
Pidana & \multicolumn{2}{r}{ Korupsi } \\
sebagaimana & telah diubah & din \\
dan ditambah & dengan UU \\
No. 20 & Th. 2001 \\
tentang & perubahan \\
atas UU No. & $31 \quad$ Th \\
1999 & \multicolumn{2}{c}{ tentang } \\
Pemberantasan & Tindak \\
Pidana Korupsi jo Pasal 55 \\
ayat (1) ke-1 jo Pasal 64 \\
ayat (1) KUHPidana
\end{tabular} & $\begin{array}{lr}4 & \text { tahun } \\
\text { paling } & \text { lama } \\
\text { tahun } & \text { atau } \\
\text { pidana } & \text { seumur } \\
\text { hidup } & \end{array}$ & $\begin{array}{l}\mathrm{Rp} \quad 200 \mathrm{juta} \text { juta } \\
\text { dan paling banyak Rp } \\
1 \text { milyar }\end{array}$ \\
\hline \multirow{2}{*}{\multicolumn{2}{|c|}{ Tuntutan Jaksa }} & \multirow{2}{*}{\multicolumn{3}{|c|}{$\begin{array}{l}\text { Pidana penjara: } 7 \text { (tujuh) tahun,dikurangi masa tahanan. } \\
\text { Denda: Rp250.000.000,- subsidair } 6 \text { (enam) bulan kur } \\
\text { Biaya perkara: Rp10.000,- } \\
\text { Putusan yang dijatuhkan kepada terdakwa }\end{array}$}} \\
\hline & & & & \\
\hline $\begin{array}{l}\text { Putusan Hal } \\
\text { Atas } \\
\text { H.Suwarna } \\
\text { Fatah }\end{array}$ & $\begin{array}{l}\text { Kasus } \\
\text { Abdul }\end{array}$ & 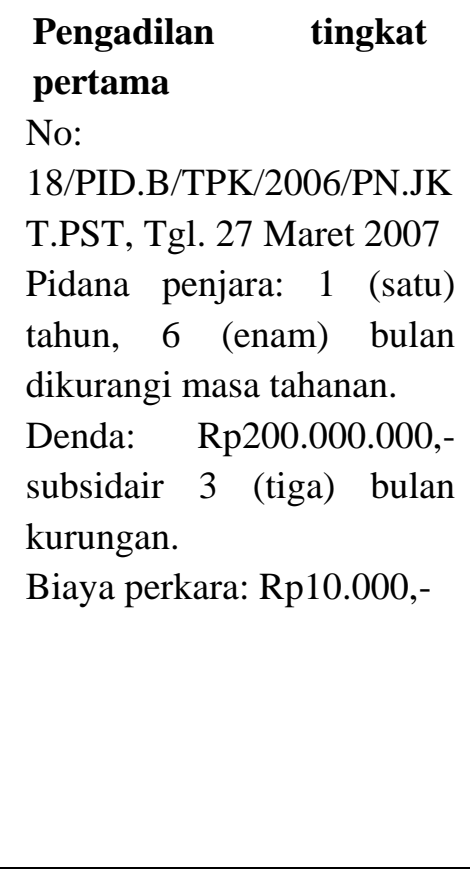 & 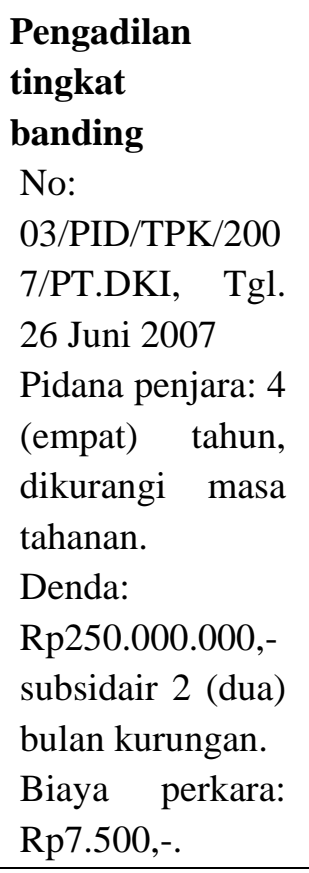 & $\begin{array}{l}\text { Pengadilan tingkat } \\
\text { kasasi } \\
\text { No: } 380 \text { K/PID/2007, } \\
\text { Tgl. } 7 \text { Desember 2007 } \\
\text { Menolak permohonan } \\
\text { kasasi dari JPU pada } \\
\text { Kejaksaan Negeri } \\
\text { Jakarta Pusat dan } \\
\text { Suwarna Abdul Fatah } \\
\text { tersebut. } \\
\text { Biaya perkara: } \\
\text { Rp2.500,-. }\end{array}$ \\
\hline
\end{tabular}

22 “ https://Acch.Kpk.Go.Id/Id/Jejak-Kasus/211-Martias-Alias-Pung-Kian-Hwa.,” AntiCorruption Clearing House, n.d., https://acch.kpk.go.id/id/jejak-kasus/211-martias-alias-pung-kian-hwa. . 
Berdasarkan data dari Tabel 3 pada kasus Martias Alias Pung Kian Hwa dan Tabel 4 pada kasus H. Suwarna Abdul Fatah, kasus tersebut adalah penyalahgunaan perizinan yaitu secara peraturan teknis menyalahi peraturan perundang-undangan berkaitan dengan kehutanan dan perkebunan, namun izin tetap dikeluarkan. Dasar hukum yang dikenakan adalah Pasal 2 ayat (1) dan Pasal 3 UUPTPK yaitu korupsi merugikan keuangan negara. Penggunaan Pasal 2 ayat (1) dan Pasal 3 UUPTK di dasarkan pada ketentuan Pasal 14 UUPTPK dimana ketentuan dalam UU tersebut harus tegas dinyatakan sebagai tindak pidana korupsi.

Membahas mengenai penyalahgunaan perizinan di sektor perkebunan kelapa sawit, tidak dapat dilepaskan dengan Undang-Undang Nomor 41 Tahun 1999 tentang Kehutanan, ${ }^{23}$ karena dalam beberapa kasus ada perizinan untuk perkebunan kelapa sawit, berhubungan dengan pelapasan kawasan hutan. UU No.41 Tahun 1999 mengatur mengenai tindak pidana di bidang kehutanan yaitu dalam Bab XIV tentang Pidana yang diatur dalam Pasal 78 sampai Pasal 79.

Berdasarkan Bab XIV dalam Pasal 78 sampai Pasal 79 UU No.41 Tahun 1999 tentang Kehutanan, mengatur sendiri tindak pidana di bidang kehutanan, dengan demikian berdasarkan ketentuan Pasal 14 UUPTK, maka tidak dapat mengkategorikan tindak pidana penyalahgunaan izin di bidang kehutanan sebagai tindak pidana korupsi.

Undang-Undang No.39 Tahun 2014 tidak ada menyatakan bahwa pelanggaran terhadap tentang Perkebunan sebagai tindak pidana korupsi. Undang-Undang Perkebunan mengatur sendiri ketentuan pidana yang diatur sendiri dalam Pasal 103 sampai dengan 113, sebagai contoh dalam penelitian ini ditampilkan salah satu pelanggaran dalam masalah penerbitan izin yang diatur dalam Pasal 106 yaitu:

menteri, gubernur dan bupati/wali kota yang berwenang menerbitkan izin usaha perkebunan yang:

a. menerbitkan izin yang tidak sesuai dengan peruntukkan; dan/ atau

b. menerbitkan izin yang tidak sesuai dengan syarat dan ketentuan peraturan perundang-undangan;

sebagaimana dimaksud dalam Pasal 50 dipidana dengan pidana penjara paling lama 5 (lima) tahun atau denda paling banyak Rp5.000.000.000,00 (lima miliar rupiah)

Seharusnya pelanggaran terhadap penyalahgunaan perizinan di sektor perkebunan menggunakan ketentuan Pasal 106 UU Perkebunan, sehingga

\footnotetext{
${ }^{23}$ Undang-Undang RI, “Undang-Undang Nomor 41 Tahun 1999 Tentang Kehutanan” (1999).
} 
terhadap tindak pidana penyalahgunaan izin di sektor perkebunan kelapa sawit menggunakan Pasal 2 ayat (1) dan Pasal 3 UUPTPK, karena berdasarkan ketentuan Pasal 14 UUPTK ketentuan di luar UUPTK harus menyatakan secara tegas bahwa pelanggaran terhadap terhadap ketentuan undang-undang tersebut sebagai tindak pidana korupsi maka berlaku UUPTPK.

\section{B. Kebijakan Formulasi Terhadap Tindak Pidana Penyalahgunaan Perizinan}

Dalam upaya penanggulangan kejahatan pada hakikatnya merupakan bagian integral dari upaya perlindungan masyarakat (social defence) dan upaya mencapai kesejahteraan masyarakat (social welfare). Oleh karena itu, dapat dikatakan bahwa tujuan akhir atau tujuan utama dari kebijakan hukum pidana adalah perlindungan masyarakat untuk mencapai kesejahteraan masyarakat. ${ }^{24}$

Berkaitan dengan keberadaan Pasal 14 UUPTPK yang harus menyatakan secara tegas bahwa pelanggaran terhadap terhadap ketentuan undangundang tersebut sebagai tindak pidana korupsi maka berlaku UUPTPK. Ketentuan undang-undang di luar UUPTPK seperti Undang-Undang Nomor 39 Tahun 2014 tentang Perkebunan, yang hendak ditarik dalam tindak pidana korupsi, karena dianggap merugikan negara, maka harus dilakukan revisi terhadap undang-undang tersebut. Agar terjadi sinkronisasi antara peraturan yang satu dengan yang lainnya.

Dalam bentuk sistem hukum yang baik, ditentukan oleh struktur yaitu kelembagaan dalam peradilan yaitu badan penyidik, badan penuntutan, badan mengadili dan badan pelaksana pidana. Selain itu sistem hukum dipengaruhi oleh substansi yaitu norma, aturan, yaitu produk berupa hukum yang dihasilkan oleh orang yang berada dalam sistem itu, berupa keputusan yang mereka keluarkan, aturan baru yang mereka susun. ${ }^{25}$

Pada aspek substansi hukum, selama ini instrumen hukum pidana di berbagai peraturan perundang-undangan di luar peraturan perundangundangan UUPTPK, seharusnya mengatur berbagai pasal tentang korupsi, sebagaimana ditegaskan dalam Pasal 14 UUPTPK, harusnya perbuatan pidana yang diatur dalam undang-undang lain tersebut memiliki unsur yang lengkap menurut rumusan korupsi di Indonesia. Selama ini secara substansi beberapa peraturan perundang-undangan tidak memuat secara tegas sebagai tindak pidana korupsi, seperti UU Kehutanan, UU Perkebunan, UU Perlindungan dan Pengelolaan Lingkungan Hidup, UU Pertambangan UU Monopoli, UU

${ }^{24}$ Barda Nawawi Arief, Kebijakan Hukum Pidana ; Perkembangan Penyusunan Konsep KUHP Baru (Jakarta: Prenada Media Group, 2011).

${ }_{25}$ IGM Nurdjana, Korupsi Dalam Praktik Bisnis (Jakarta: Gramedia, 2005). 
Perpajakan, serta peraturan perundang-undangan yang mengatur dimensi baru (new dimention crime). ${ }^{26}$ Bentuk-bentuk lain korupsi dengan modus dimensi baru misalnya melalui Illegal logging, Illegal Fishing, Illegal Labour, Cyber Crime, Corporate Crime, Customer Fraud dan sebagainya, sehingga tepatlah konvensi Internatioal PBB tanggal 7 Oktober 2003 menetapkan "corruption" sebagai extra ordinary crime, yang tergolong dalam white collar crime, secara substansi unsur-unsur pidana yang ada di dalam peraturan perundang-undangan tersebut sangatlah potensial sebagai tindak pidana korupsi, mengingat kerugian keuangan negara yang sangat besar ditemukan dalam rumusan pasal-pasal yang memenuhi unsur-unsur delik korupsi atau tindak pidana korupsi. ${ }^{27}$

Kerugian keuangan negara di sektor perkebunan kelapa sawit, data Kementerian Kehutanan tebaru yaitu pada Agustus 2011 lalu menyebutkan potensi kerugian negara akibat izin pelepasan kawasan hutan di 7 provinsi di Indonesia diprediksi merugikan negara hampir Rp 273 triliun. Kerugian negara tersebut timbul akibat pembukaan 727 Unit Perkebunan dan 1.722 unit pertambangan yang dinilai bermasalah. ${ }^{28}$ Dari jumlah kerugian negara yang terjadi, Kalimantan Tengah merupakan yang terbesar yaitu Rp 158 triliun. Lebih besar dibandingkan dengan provinsi lainnya seperti Kalimantan Timur yang nilainya diduga mencapai Rp 31,5 triliun, Kalimantan Barat sebesar Rp 47,5 triliun dan Kalimantan Selatan mencapai Rp 9,6 triliun. ${ }^{29}$

Sementara itu saat ini, politik hukum pidana terhadap tindak pidana korupsi terjadi pergeseran sikap, hal ini ditandai dengan lahirnya UU No.19 Tahun 2019 tentang Perubahan atas Undang-Undang Nomor 30 Tahun 2002 tentang Komisi Pemberantasan Korupsi. ${ }^{30}$ Kemudian UUPTPK juga mengalami perubahan. Pada sistem substansial merupakan materi hukum yang mempengaruhi penegakan hukum tindak pidana korupsi, seperti hukum pidana materiil yaitu UUPTPK yang masih memiliki kekurangan dan terjadi pelemahan. Pertama penjelasan Pasal 2 ayat (1) UUPTPK (UU No.31/1999) oleh Mahkamah Konstitusi tanggal 25 Juli 2006 mengeluarkan putusan Nomor 003/PUU-IV/2006 yang menyatakan tidak mempunyai kekuatan hukum mengikat mengenai penjelasan Pasal 2 ayat (1) Undang-Undang Nomor 31 Tahun 1999 tentang Pemberantasan Tindak Pidana Korupsi sebagaimana dirubah dengan Undang-Undang Nomor 20 Tahun 2001 tentang Perubahan

27 IGM Nurdjana, Sistem Hukum Pidana Dan Bahaya Laten Korupsi Perpsektif Tegaknya Keadilan Melawan Mafia Hukum (Yogyakarta: Pustaka Pelajar, 2010).

28 Yuntho, "Potret Korupsi Di Sektor Perkebunan Sawit."

29 Yuntho.

30 Undang-Undang RI, "UU No.19 Tahun 2019 Tentang Perubahan Atas Undang-Undang Nomor 30 Tahun 2002 Tentang Komisi Pemberantasan Korupsi.” (2019). 
atas Undang-Undang Nomor 31 Tahun 1999 tentang Pemberantasan Tindak Pidana Korupsi (UU PTPK) (Lembaran Negara Republik Indonesia Tahun 2001 Nomor 134 Tambahan Lembaran Negara Republik Indonesia Nomor 4150

Konsep melawan hukum yang secara formil tertulis (formele wederrechtelijk) yang mewajibkan pembuat undang-undang, untuk merumuskan secermat dan serinci mungkin merupakan syarat untuk menjamin kepastian hukum (lex certa), atau yang dikenal juga dengan istilah Bestimmheitsgebot. ${ }^{31}$

Kemudian frasa kalimat "dapat" pada unsur "yang dapat merugikan keuangan negara atau perekonomian negara" dalam rumusan Pasal 2 ayat (1) dan Pasal 3 UUPTPK oleh mahkamah konstitusi dinyatakan tidak mempunyai kekuatan hukum mengikat. Putusan Mahkamah Konstitusi No.25/PUUXIV/2016. Dalam putusannya, Mahkamah Konstitusi menilai Pasal 2 ayat (1) dan Pasal 3 UU Tipikor terkait penerapan unsur merugikan keuangan negara telah bergeser dengan menitikberatkan adanya akibat (delik materiil). Tegasnya, unsur merugikan keuangan negara tidak lagi dipahami sebagai perkiraan (potential loss), tetapi harus dipahami benar-benar sudah terjadi atau nyata (actual loss) dalam tindak pidana korupsi. ${ }^{32}$

Dengan putusan Mahkamah Konstitusi No.25/PUU-XIV/2016 merubah delik korupsi dalam Pasal 2 ayat (1) dan Pasal 3 UUPTPK dari delik formil (delik perbuatan yang dilarang), selama ini cukup berupa perkiraan (potential loss)I dari kerugian keuangan negara, menjadi delik materiil (akibat yang dilarang) nyata (actual loss) benar-benar terjadi dari kerugian keuangan negara. Berdasarkan hasil penelitian mahasiswa Universitas Lambung Mangkurat, penegak hukum (kepolisian dan kejaksaan) tidak berani mengusut kasus tindak pidana korupsi, apabila belum ada kerugian keuangan negara secara nyata. Tentu hal ini akan menghambat pemberantasan tindak pidana korupsi.

Menurut Mispansyah, korupsi adalah "sebuah kejahatan yang tersistematis dan merupakan kejahatan terorganisir, korupsi merupakan kejahatan yang terstruktur yang sangat utuh, mengakar, kuat dan permanen sifatnya." Korupsi sudah merupakan bagian dari "sistem" yang ada, karenanya suatu usaha yang maksimal bagi penegakan hukum, khususnya pemberantasan

31 Mahkamah Konstitusi. "Putusan Nomor 003/PUU-IV/2006”, Mahkamah Konstitusi Republik Indonesia, 2006, Jakarta, hal 75

32 Agus Sahbani, "Begini Alasan MK Ubah Delik Tipikor," HukumOnline.com, 2017, https://www.hukumonline.com/berita/baca/lt5888f5b5bb039/begini-alasan-mk-ubah-delik-tipikor/. 
tindak pidana korupsi, harus dilakukan dengan pendekatan sistem, ${ }^{33}$ yaitu substansi hukum atau materi hukum, struktur, dan budaya hukum termasuk di dalamnya peran serta masyarakat dalam pemberantasan korupsi di sektor sumber daya alam. ${ }^{34}$ Dalam membentuk budaya hukum termasuk dalam hal ini adalah pendidikan anti korupsi, untuk menanamkan dan mengganti paradigma masyarakat tentang bahaya korupsi bagi segala lini aspek kehidupan. ${ }^{35}$

Seharusnya sebagai tindak pidana luar biasa (extra ordinary crime) pengaturannya pemberantasan korupsi diprioritaskan. Substansi hukum, bidang-bidang hukum yang menunjuk ekonomi dan pembangunan pada prioritas pembentukkannya. Dalam praktik pembentukan hukum yang secara substansi pada peraturan perundang-undangan seharusnya memuat pasal-pasal tindak pidana korupsi seperti pada UU Monopoli, UU Pertambangan, UU Otonomi Daerah, UU Kehutanan, UU Perlindungan dan Pengelolaan Lingkungan Hidup (UUPPLH), UU Perkebunan dan UU lainnya sangat berpotensi bersinggungan dengan korupsi. Sebelumnya pembaharuan hukum dalam UU Nomor 3 tahun 1971 bahwa perkara korupsi diistimewakan, diutamakan atau dianggap luar biasa, tetapi dengan UU No.28 tahun $1998^{36}$, UU No.31 Tahun 1999 dan UU No.20 tahun 2001 Pasal yang menyebutkan korupsi istimewa hilang. ${ }^{37}$

Sebagai sebuah negara hukum, sistem hukum Indonesia didasarkan pada UUD 1945 yang menegaskan Indonesia adalah negara hukum (recht staat), tidak berdasarkan atas kekuasaan (machtstaat). ${ }^{38}$ Berdasarkan itu, untuk dapat menarik kasus penyalahgunaan perizinan di sektor perkebunan kelapa sawit dalam Undang-Undang Perkebunan, maka harus melakukan revisi terhadap UU No.39 tahun 2014 mengenai pasal yang berkaitan dengan penyalahgunaan perizinan perkebunan merupakan tindak pidana korupsi. UU

\footnotetext{
${ }^{33}$ Mispansyah, "A Comparison Approach in Corruption Eradication: An Empirical Examination," Hasanuddin Law Review 4, no. 2 (2018): 221, https://doi.org/http://dx.doi.org/10.20956/halrev.v4i2.1077.

${ }^{34}$ Epakartika Epakartika, Rizky Nugraha Murnawan, and Agung Budiono, "Peran Masyarakat Sipil Dalam Pemberantasan Korupsi Sektor Sumber Daya Alam," Integritas Jurnal Antikorupsi 5, no. 2 2 (2019): 1, https://doi.org/https://doi.org/10.32697/integritas.v5i2-2.485.

35 Mochamad Ramdhan Pratama and Mas Putra Zenno Januarsyah, "Upaya Non-Penal Dalam Pemberantasan Tindak Pidana Korupsi," Jurnal Ius Constituendum 5, no. 2 (2020): 253, https://journals.usm.ac.id/index.php/jic/article/view/2195.

36 Undang-Undang RI, "Undang-Undang No.28 Tahun 1999 Tentang Penyelenggaraan Negara Yang Bebas Korupsi, Kolusi Dan Nepotisme” (1999).

37 A.Dodri Azizy, Hukum Nasional, Elektrisisme Hukum Islam Dan Hukum Umum (Bandung: Terogu, 2004).

${ }_{38}$ Muhammad Taher Azhary, Negara Hukum, Suatu Study Tentang Suatu Prinsip-Prinsipnya Diktat Dari Segi Hukum Islam, Implementasi Pada Periode Negara Madinah Dan Masa Kini (Jakarta: Prenada Media Group, 2007).
} 
No.39 tahun 2014 yang mengatur tindak pidana izin usaha perkebunan yang diatur dalam Pasal 103, Pasal 105, Pasal 106 dan Pasal 107.

Ketentuan di atas harus direvisi agar terjadi harmonisasi ${ }^{39}$ regulasi di undang-undang perkebunan dengan menambahkan pasal yang menyatakan bahwa, tindak pidana Pasal 103, Pasal 105, Pasal 106, Pasal 107 merupakan tidak pidana korupsi. Dengan demikian maka penegak hukum tidak salah menerapkan dasar dalam UU PTPK, karena sesuai dengan ketentuan Pasal 14 UU PTPK yaitu "Setiap orang yang melanggar ketentuan undang-undang yang secara tegas menyatakan bahwa pelanggaran terhadap ketentuan undang-undang tersebut sebagai tindak pidana korupsi berlaku ketentuan yang diatur dalam undang-undang ini." Dan ketentuan pasal dalam UU PTPK yang sangat memungkinkan dikenakan kepada pelaku adalah Pasal 2 ayat (1) dan Pasal 3 yaitu mengenai korupsi.

\section{PENUTUP}

Berdasarkan pembahasan disimpulkan bahwa: Pertama, penyalahgunaan perizinan di sektor perkebunan sawit tidak tepat dikategorikan sebagai tindak pidana korupsi, karena dalam ketentuan Pasal 14 UU PTPK, karena harus ditegaskan dalam peraturan perundangan di luar UU PTPK, sedangkan UU Perkebunan Nomor 39 tahun 2014 tidak menyebutkan bahwa penyalahgunaan izin perkebunan adalah tindak pidana korupsi. Kedua, kebijakan formulasi terhadap tindak pidana penyalahgunaan perizinan perkebunan sawit dimasa mendatang, yaitu dengan melakukan revisi terhadap Undang-Undang Nomor 39 tahun 2014, dengan menambahkan ketentuan pasal yang menegaskan bahwa tindak pidana mengenai penyalahgunaan izin dalam Undang-Undang Nomor 39 Tahun 2014 merupakan tindak pidana korupsi. Penelitian ini memberikan saran kepada pemerintah dan Dewan Perwakilan Rakyat Republik Indonesia segera melakukan sinkronisasi ketentuan peraturan perundangundangan khususnya Undang-Undang Perkebunan dan Undang-Undang Kehutanan dengan UU PTPK agar kasus tindak pidana korupsi di sektor perkebunan kelapa sawit dapat di jerat.

\section{DAFTAR PUSTAKA}

Apriando, Tommy. "Kajian UGM: 2,8 Juta Hektar Kebun Sawit Di Kawasan Hutan, 65\% Milik Pengusaha, Solusinya?" Mongabay Situs Berita Lingkungan, 2018. https://www.mongabay.co.id/2018/11/04/kajianugm-28-juta-hektar-kebun-sawit-di-kawasan-hutan-65-milik-

\footnotetext{
39 Mumu Muhajir et al., "Harmonisasi Regulasi Dan Perbaikan Tata Kelola Sumber Daya Alam Di Indonesia," Integritas Jurnal Antikorupsi 5, no. 2-2 (2019): 1-2, https://doi.org/https://doi.org/10.32697/integritas.v5i2-2.479.
} 
pengusaha-solusinya/.

Arief, Barda Nawawi. Kebijakan Hukum Pidana; Perkembangan Penyusunan Konsep KUHP Baru. Jakarta: Prenada Media Group, 2011.

Azhary, Muhammad Taher. Negara Hukum, Suatu Study Tentang Suatu Prinsip-Prinsipnya Diktat Dari Segi Hukum Islam, Implementasi Pada Periode Negara Madinah Dan Masa Kini. Jakarta: Prenada Media Group, 2007.

Azizy, A.Dodri. Hukum Nasional, Elektrisisme Hukum Islam Dan Hukum Umum. Bandung: Terogu, 2004.

Cahyono, Eko, Sulistyanto Sulistyanto, and Sarah Azzahwa. "Resolusi Konflik Gerakan Nasional Penyelamatan Sumber Daya Alam: Lintasan Gagasan, Praktik, Dan Bentang Masalah.” Integritas Jurnal Antikorupsi 5, no. 22 (2019): 1. https://doi.org/https://doi.org/10.32697/integritas.v5i22.484 .

Ddisetiansah_anticorrupt. "Tindakan Korupsi Terhadap Sumber Daya Alam Yang Terjadi Di Bumi Papua." Blogger, 2012. http://riotpositive.blogspot.com/.

Epakartika, Epakartika, Rizky Nugraha Murnawan, and Agung Budiono. "Peran Masyarakat Sipil Dalam Pemberantasan Korupsi Sektor Sumber Daya Alam." Integritas Jurnal Antikorupsi 5, no. 2-2 (2019): 1. https://doi.org/https://doi.org/10.32697/integritas.v5i2-2.485.

Fauzan, Rahmad. "Korupsi DPRD Kalteng Bukti Mekanisme Izin Kelapa Sawit Belum Berjalan Baik." Bisnis.com, 2018. https://kabar24.bisnis.com/read/20181027/16/853848/korupsi-dprdkalteng-bukti-mekanisme-izin-kelapa-sawit-belum-berjalan-baik.

Hayat, and Mar'atul Makhmudah. "Pencegahan Terhadap Tindak Pidana Korupsi Pemerintahan Desa: Kajian Politik Kebijakan Dan Hukum Pengelolaan Sumber Daya Alam Desa." Yustisia Jurnal Hukum 5, no. 2 (2016): 1-2. https://doi.org/https://doi.org/10.20961/yustisia.v5i2.875.

Korupsi, Komisi Pemberantasan. Kajian Sistem Pengelolaan Komoditas Kelapa Sawit. Jakarta: Direktorat Penelitian dan Pengembangan Kedeputian Bidang Pencegahan Komisi Pemberantasan Korupsi Republik Indonesia, 2016.

Marzuki, Peter Mahmud. Penelitian Hukum. Cet Ke-3. Jakarta: Kencana Prenada Media Group, 2007.

Mispansyah. "A Comparison Approach in Corruption Eradication: An Empirical Examination." Hasanuddin Law Review 4, no. 2 (2018): 221. https://doi.org/http://dx.doi.org/10.20956/halrev.v4i2.1077.

Muhajir, Mumu, Maria SW Sumardjono, Timer Manurung, and Julius Ferdinand. "Harmonisasi Regulasi Dan Perbaikan Tata Kelola Sumber Daya Alam Di Indonesia." Integritas Jurnal Antikorupsi 5, no. 2-2 (2019): 1-2. https://doi.org/https://doi.org/10.32697/integritas.v5i22.479 .

Muhdar, Muhamad. "Rekonstruksi Basis Perhitungan Kerugian Negara Dalam Peristiwa Tindak Pidana Korupsi Pada Sektor Sumber Daya Alam.” Jurnal de Jure 12, no. 1 (2020): 1-2. https://jurnal.law.uniba- 
bpn.ac.id/index.php/jurnaldejure/article/view/374.

Nagara, Grahat, Belinda Sahadati Amri, Dian Patria, and Farid Andhika. "Persoalan Struktural Dalam Politik Penegakan Hukum Sumber Daya Alam Dan Lingkungan Hidup." Integritas Jurnal Antikorupsi 5, no. 2-2 (2019): 1. https://doi.org/https://doi.org/10.32697/integritas.v5i2-2.483.

Anti-Corruption Clearing House. "No Titlehttps://Acch.Kpk.Go.Id/Id/JejakKasus/211-Martias-Alias-Pung-Kian-Hwa.," n.d. https://acch.kpk.go.id/id/jejak-kasus/211-martias-alias-pung-kian-hwa.

Nurdjana, IGM. Korupsi Dalam Praktik Bisnis. Jakarta: Gramedia, 2005.

—. Sistem Hukum Pidana Dan Bahaya Laten Korupsi Perpsektif Tegaknya Keadilan Melawan Mafia Hukum. Yogyakarta: Pustaka Pelajar, 2010.

Pratama, Mochamad Ramdhan, and Mas Putra Zenno Januarsyah. "Upaya Non-Penal Dalam Pemberantasan Tindak Pidana Korupsi." Jurnal Ius $\begin{array}{llllll}\text { Constituendum } & 5, & \text { no. } & 2 & \text { (2020): } & 253 .\end{array}$ https://journals.usm.ac.id/index.php/jic/article/view/2195.

“Pusat Kajian Informasi Pertanian, No 01/01/I.” Jakarta, 2013.

Rasad, Fauziah. "Korupsi Dan Hak Asasi Manusia Dalam Sektor Kehutanan." $\begin{array}{llllll}\text { Jurnal HAM } & \text { 9, } & \text { no. } & 2 & \text { (2018): } & 1 .\end{array}$ https://doi.org/http://dx.doi.org/10.30641/ham.2018.9.121-138.

Sahbani, Agus. "Begini Alasan MK Ubah Delik Tipikor.” HukumOnline.com, 2017.

https://www.hukumonline.com/berita/baca/lt5888f5b5bb039/beginialasan-mk-ubah-delik-tipikor/.

Soekanto, Soerdjono, and Sri Mamudji. Penelitian Hukum Normatif Suatu Tinjauan Singkat. Cet Ke-14. Jakarta: PT.RajaGrafindo Persada, 2012.

Soekanto, Soerjono. Pengantar Penelitian Hukum. Cet Ke-3. Jakarta: Universitas Indonesia, 1986.

Undang-Undang RI. Undang-Undang No.28 Tahun 1999 tentang Penyelenggaraan Negara yang Bebas Korupsi, Kolusi dan Nepotisme (1999).

- Undang-Undang No.31 Tahun 1999 sebagaimana diubah dengan Undang-Undang Nomor 20 Tahun 2001 tentang Pemberantasan Tindak Pidana Korupsi (2001).

—. Undang-Undang Nomor 39 Tahun 2014 tentang Perkebunan (2014).

_. Undang-Undang Nomor 41 Tahun 1999 tentang Kehutanan (1999).

—. UU No.19 Tahun 2019 tentang Perubahan atas Undang-Undang Nomor 30 Tahun 2002 tentang Komisi Pemberantasan Korupsi. (2019).

UUD 1945. Undang-Undang Dasar Negara Republik Indonesia Tahun 1945 (n.d.).

Yuntho, Emerson. "Potret Korupsi Di Sektor Perkebunan Sawit." Jurnal Toddoppuli, 2014, 1-5. https://jurnaltoddoppuli.wordpress.com/2014/10/20/potret-korupsi-disektor-perkebunan-sawit/.

Yuwanto, Listyo. "Kinerja Penanganan Tindak Pidana Korupsi Sumber Daya Alam Dan Kepercayaan Terhadap Komisi Pemberantasan Korupsi." 
Penyalahgunaan Perizinan Perkebunan Sawit Dalam

Perspektif Tindak Pidana Korupsi

Mispansyah Mispansyah, Nurunnisa Nurunnisa

p-ISSN : 2541-2345, e-ISSN : 2580-8842

Integritas Jurnal Antikorupsi 2, no. 1 (2016): 1. https://doi.org/https://doi.org/10.32697/integritas.v2i1.137. 